\title{
Lucidez poética em Ave, Palavra, de Guimarães Rosa
}

\author{
Érica Alves Rossi \\ Universidade Federal de Mato Grosso do Sul (UFMS), Três Lagoas, \\ Mato Grosso do Sul, Brasil \\ erica_a_rossi@yahoo.com.br \\ https://orcid.org/0000-0002-9102-4504
}

DOI: http://dx.doi.org/10.21165/el.v47i3.1954

\begin{abstract}
Resumo
O presente trabalho propõe uma leitura de composições poéticas de João Guimarães Rosa publicadas no livro híbrido Ave, Palavra (1970). Partimos da perspectiva de que os poemas rosianos filiam-se ao que Octavio Paz (1993) denominou de "poesia de convergência", herança do diálogo entre dois extremos advindos da produção romântica, a analogia e a ironia. Atendonos à tendência nomeada como ironia, destacamos, dentre as produções do referido livro, quatro composições que promovem a sondagem da criação literária. Como método de análise, serão feitas aproximações dos poemas com outras obras do autor e com demais textos de Guimarães Rosa que sondam o fazer literário, como a entrevista dada pelo artista a Günter Lorenz (1973), as correspondências trocadas com seu tradutor italiano Edoardo Bizzarri (1980) e trechos de prefácios que compõem Tutameia (ROSA, 1976). A leitura, portanto, busca analisar como tais questões que inquietaram Rosa se realizam em suas composições em verso, ora a partir de narrativas embrionárias, alegóricas, ora valendo-se de composições de tom mais lírico, trazendo à tona imagens recorrentes em suas produções, evidenciando que suas poesias não são um mero acidente, mas compõem o projeto estético do autor.
\end{abstract}

Palavras-chave: poesia moderna; Guimarães Rosa; poesia de convergência.

\section{Poetic lucidity in Ave, Palavra, by Guimarães Rosa}

\begin{abstract}
This paper proposes an analysis of the poetic compositions written by João Guimarães Rosa published in his hybrid book Ave, Palavra (1970). We start from the perspective that his poems are based on what Octavio Paz (1993) called "poesia de convergência", inheritance of the dialogue between two extremes arising from romantic production: analogy and irony. Taking into account the tendency as irony, we highlight among the author's productions four compositions that promote the exploration of literary creation. As a method of analysis, approximations of the poems will be made with other works and other texts which probe the literary work, such as the interview given by the artist to Günter Lorenz (1973), the correspondence exchanged with his Italian translator Edoardo Bizzarri (1980) and sections of prefaces of Tutameia (ROSA, 1976). The reading, therefore, seeks to analyze how such disturbing questions perform in his poems, sometimes from embryonic narratives, allegorical, sometimes using compositions with a more lyrical tone, bringing to the surface recurrent images in their productions, evidencing that his poetry is not just an accident, but it composes the aesthetic project of the author.
\end{abstract}

Keywords: modern poetry; Guimarães Rosa; convergence poetry. 


\section{Introdução}

A literatura produzida por Guimarães Rosa é herdeira de valores e tendências que marcam as produções artísticas do século XX. Octavio Paz caracteriza esse momento literário como esmaecedor de uma "tradição da ruptura" instaurada na modernidade. Presente em todos os momentos da poesia, mas intensificada no fim do século passado, a arte poética contemporânea, dirá o poeta e ensaista mexicano, configura-se como reconciliação das duas metades da esfera: o corpo e a alma, o presente e o passado, o eu e o tu, na busca do poeta pelo encontro com o seu "eu" cindido. Tal poesia "busca a interseção dos tempos, o ponto de convergência" (PAZ, 1993, p. 56-57). No entanto, convive também nesse novo artista o fascínio pelo conhecimento, pela inovação, tomando forma através da experimentação estética e da apropriação do fazer poético como seu objeto de inspiração. A nova poesia seria a herança do diálogo entre dois extremos advindos da produção romântica: a analogia e a ironia. A analogia "[...] se insere no mito; sua essência é o ritmo, quer dizer, o tempo cíclico feito de aparições e desaparições, mortes e ressurreições". Gêmea adversária, a ironia "é a manifestação da crítica no reino da imaginação e da sensibilidade; sua essência é o tempo sucessivo que desemboca na morte" (PAZ, 1993, p. 38). As duas vertentes, analogia e ironia, concretizam-se nos poemas do autor por meio da busca da identidade a partir do outro e da consciência do fazer poético, da metapoesia, em especial nas composições em verso de Ave, Palavra.

No presente artigo, delimitaremos a análise às composições em que a palavra literária é também a musa da poesia em estudo. Destacamos, dentre as composições da coletânea, quatro poemas que essencialmente têm por tema o fazer literário, promovendo a sondagem da criação, temática e constitutivamente. São eles: "Motivo", "Distância", "Escólio" e "Tornamento". O método de análise dá-se por aproximações com outras obras e demais textos do autor que sondam o fazer literário, como a entrevista dada pelo artista a Günter Lorenz (ROSA apud LORENZ, 1973), as correspondências trocadas com seu tradutor italiano Edoardo Bizzarri (1980) e trechos dos prefácios que compõem Tutaméia (ROSA, 1976). A utilização dos referidos textos rosianos justifica-se pela tendência moderna, que atinge os artistas desse período, de pensar o próprio fazer literário.

Com o desenvolvimento de uma corrente literária auto-referencialista, os poetas modernos, após Baudelaire, veem a necessidade de teorizar sobre a poesia que constroem. Maciel (1999, p. 22) ressalta que, a partir deste e dos movimentos anteriores, surgiram, além do poema-crítico, “[...] textos críticos em prosa, sob a forma de ensaios, manifestos, fragmentos, cartas e depoimentos, que, do Romantismo até hoje, precedem, acompanham ou elucidam as obras poéticas de seus autores”. Leonel (2000, p. 67), ao referir-se sobre Guimarães Rosa, afirma que

[...] há, a reger a produção rosiana, uma poética, um projeto estético de que o escritor pode não ter consciência plena, mas que tende a explicitar em muitos momentos. Aliás Guimarães Rosa encaixa-se entre aqueles autores que se comprazem em pensar o seu ofício, em determinar o conceito de obra literária, as suas direções, de modo claro e muitas vezes didático na correspondência e em escritos paratextuais e de maneira explícita e implícita na produção artística. 
Como artista moderno interessado no processo de renovação da linguagem, Rosa filia-se aos poetas preocupados em repensar o fazer literário. Ao longo do presente artigo, surgirão demonstrações de que o autor mineiro entende que é também no bojo da escritura artística que se discute e contempla seu próprio conceito.

\section{A reflexão do fazer literário presente nos poemas rosianos}

A partir da perspectiva apresentada anteriormente, seguimos para a análise dos poemas citados. Iniciamos com "Distância" (p. 105), poema atribuído a Sá Araujo Ségrim, um dos anagramas do autor, em que é narrada uma viagem frustrada de um cavaleiro e um cachorro, que se perdem na história:

\section{DISTÂNCIA}

Um cavaleiro e um cachorro

viajam para a paisagem.

Conseguiram que esse morro

não lhes barrasse a passagem.

Conseguiram um riacho

com seus goles, com sua margem.

Conseguiram boa sede.

Constataram:

cai a tarde.

Sobre a tarde, cai a noite,

sobre a noite, a madrugada.

Imagino o cavaleiro

testa orvalhada e estrelada.

$O$ pensar do cavaleiro

talvez o amar, ou nem nada.

Imagino o cachorrinho

imaginário na estrada.

Caía a tarde.

Para a tarde o cavaleiro

ia, conforme avistado.

Após, também o cachorro.

Todos - iam, de bom grado,

à tarde do cavaleiro

do cachorro, do outro lado

- que na tarde se perderam,

no morro, no ar, no contado.

Caiu a tarde.

Em "Distância", a (ir)realidade literária é revelada ao leitor: "Imagino o cachorrinho/ imaginário na estrada". O poeta, como se vê, desnuda o fingimento literário e, no próprio corpo do texto, menciona seu caráter ficcional. No livro A Experiência do Fora, Levy (2003) ressalta a mudança paradigmática ocorrida na literatura do século XX, anunciada por escritores como Mallarmé, Kafka e Proust. Tal rompimento com premissas fundamentais de uma determinada concepção de realismo 
literário que objetivavam dar conta dos mínimos detalhes da realidade foi substituído pela proposta de enfatizar o ato da criação e a realidade própria da literatura. Em "Distância", as figuras apresentam-se, antes de tudo, como ficção.

Nos primeiros versos, diz-se das duas personagens - o cavaleiro e o cachorro que viajam para a paisagem. Ao buscarmos o significado do termo "paisagem", encontramos uma definição que abarca não apenas o real empírico, mas que também abrange o caráter de representação: "1. Espaço de terreno que se abrange num lance de vista. 2. Pintura, gravura ou desenho que representa uma paisagem natural ou urbana" (FERREIRA, 2004, p. 1468, grifo nosso). Embora as personagens viajem para a paisagem, ela não está terminada, e, sim, vai sendo construída ao longo do texto. Na primeira estrofe, o morro, o riacho (com seus goles e sua margem) são "conseguidos" pelas personagens. "Conseguir" denota realização, alcance de um objetivo: pode-se pensar, também, que o cavaleiro e o cachorro viajam para elaborar a paisagem, tendo no morro e no riacho as suas primeiras conquistas.

$\mathrm{Na}$ segunda estrofe, o verbo em primeira pessoa surge no poema, inserindo o eu poético no texto. A presença personificada do poeta, em meio a uma linguagem até então narrativa, não traz à composição novos acontecimentos, o eu poético divaga, libera sua imaginação em ações que não se realizam pela história contada nos versos anteriores nem, tampouco, presentificam-se nos posteriores. Tais divagações são apresentadas pelo eu poético no terreno do imaginário, onde desejo ainda não realizado acena como uma realização poética máxima: "Sobre a tarde, cai a noite,/ sobre a noite, a madrugada./ Imagino o cavaleiro/ testa orvalhada e estrelada/ O pensar do cavaleiro/ talvez o amar, ou nem nada./ Imagino o cachorrinho/ imaginário na estrada./ Caía a tarde". Essa conquista imagética viria através da madrugada, que orvalharia e estrelaria o rosto do cavaleiro. No entanto, o cavaleiro não consegue transpor a tarde e a noite, atingindo a madrugada, o "outro lado". Ele se perde na tarde, no contado, na narrativa: "Todos - iam, de bom grado, à tarde do cavaleiro/ do cachorro, do outro lado/ - que na tarde se perderam,/ no morro, no ar, no contado./ Caiu a tarde" (grifo nosso).

A imagem (paisagem) seria construída no tempo e, por isso, tendente à narrativa. É importante notar a presença do verbo "cair" no final de cada estrofe, conjugado em tempos verbais distintos. Em um primeiro momento, o verbo surge no presente do indicativo: "Cai a tarde". Trata-se, como o próprio poema indica, da constatação de um ambiente, do ambiente inicial de construção literária. Na segunda estrofe - constituída pela imaginação liberta do poeta, que daria margem ao desenrolar da história - o verbo está no pretérito imperfeito do indicativo, consagrado por ser o tempo verbal típico da linguagem narrativa, o qual se perdura no tempo através de um passado perpetuado. $\mathrm{Na}$ última estrofe, o verbo cair apresenta-se no pretérito perfeito que caracteriza um passado concluído, ultrapassado. É determinado por esse tempo verbal que o poema termina, mas com sabor de narrativa gorada.

Não se tem ou busca, portanto, apenas um lugar, mas um desenrolar temporal. Esse discurso marcado no tempo é tampouco suficiente para realizar a narrativa literária, é necessária a fantasia, a inventividade representada pela segunda estrofe. O cachorrinho imaginado, inventado, pode significar, no texto, a palavra literária, ao lado do cavaleiro, o poeta. Juntos, caminhariam em busca da criação literária, que ultrapassa a linguagem convencional e atinge o mito, o outro lado, devolvendo à palavra o seu poder de criação. 
Na segunda estrofe, em que se alude à realização plena do fazer literário, o poeta refere-se ao "nada" como o pensamento do poeta e o "outro lado" como destino final das personagens. Tanto o "outro lado" quanto o "nada" reportam-nos ao âmbito da transcendência. Outro recurso explorado é a sonoridade da palavra "morro", que acena também para o campo do transcendental. Além de aludir a "pequeno monte", harmônico em sua construção da paisagem, "morro" também nos lembra morte: morro, obstáculo a superar; morro, morte a transcender. "Distância" torna-se exemplar para ilustrar a analogia que o escritor mineiro estabelece entre renovação humana e renovação da língua. Fantini (2004, p. 51), afirma que

Não raras são as situações em que Guimarães Rosa relaciona a renovação da língua à renovação do mundo. Sabe-se, ademais, que uma das principais metas incluídas em seu "projeto de longo alcance" era a criação de uma literatura feita para perdurar, no mínimo, até o próximo milênio. Um dos documentos a atestar tal propósito é o acervo espistolar de Meyer-Clason, de onde se pode recortar esta surpreendente afirmativa de Rosa: "A gente tem de escrever para setecentos anos. Para o Juízo Final. Nenhum esforço suplementar fica perdido".

"Distância", pequena peça literária, ilustra uma narrativa falhada que finda sem ter conseguido se perpetuar no tempo. As personagens caminhavam para o "outro lado", mas se perderam na história, na paisagem. O próprio título - "Distância" - alude à não realização do alcance. Como texto literário, o poema se realiza ao ilustrar, paradoxalmente, uma narrativa que não se realiza enquanto obra de arte.

Outra característica da literatura moderna presente nesse poema e também em outros da coletânea, a exemplo de "Ou...ou", "O aloprado", "Pescaria", "Parlenda" e "Teorema" é a busca da despersonalização, que rompe a unidade entre poesia e pessoa empírica. Diz Levy (2003, p. 40) que, através do distanciamento do "eu", a obra é aproximada do leitor: "Atingir o ele significa abrir a possibilidade de todos experimentarem a literatura. Um discurso sem eu é um discurso de todos, um discurso de ninguém". Ainda que em "Distância" esteja presente o discurso em primeira pessoa, é o poeta enquanto criador quem fala, numa ânsia pela plena realização artística.

"Motivo" (p. 55), atribuído ao anagramático Soares Guiamar, é outro poema em que o artista privilegia o aspecto metaliterário. $\mathrm{O}$ poeta nos põe a par da viagem imaginária de um menino que, assim como em "Distância", tem sua travessia frustrada:

\author{
MOTIVO \\ O menino foi andando \\ entrou num elevador \\ a casa virou montanha \\ o luar partiu-a em três \\ o menino saiu de selvas \\ montado no gurupés \\ adormeceu sobre neve \\ despertou noutro cantar \\ mas deu-se que envelhecera \\ bem antes de despertar \\ então ele veio andando
}


só podia regressar

ao porquê, ao onde, ao quando

- a causa, tempo e lugar.

Do mesmo modo que em "Distância", "Motivo" é um poema de versos heptassílabos, sendo exploradas, um tanto regularmente - mas não de modo rigoroso as rimas finais dos versos. Os dois poemas aproximam-se pela linguagem simples e pelo seguimento, ainda que não religiosamente, às convenções poéticas, das trovas criadas pela poesia de caráter popular.

Uma figura recorrente que surge em "Motivo" é a da montanha. Em "Os três burricos", outro poema de Ave, Palavra, o eu poético vai "por estradas de montanha"; em "Distância", como vimos, "morro" é figura explorada semântica e sonoramente. Em entrevista a Günter Lorenz, Guimarães Rosa também faz menção à montanha. Uma das vezes em que esta figura surge é quando o escritor intitula-se feiticeiro da palavra e explica que, para realizar a magia linguística, é necessário que o feiticeiro provenha do sertão: "Levo o sertão dentro de mim e o mundo no qual vivo é também o sertão. Estes são os paradoxos incompreensíveis, dos quais o segredo da vida irrompe como um rio descendo das montanhas" (ROSA apud LORENZ, 1973, p. 342). Nas três composições citadas, é narrado o percurso de uma viagem e, nesse contexto, a montanha surge como obstáculo a superar, momento de aprendizagem ao qual se submetem o eu poético e/ou as personagens.

"Distância" e "Motivo" têm por tema a criação literária, porém, ao segundo poema, Guimarães Rosa reserva a linguagem alegórica para sua construção. "Motivo" pode ser lido como alegoria da linguagem que não se realiza como palavra literária. Vejamos como tal leitura pode ser validada no contexto rosiano.

Dentro da ficção brasileira, Rosa é reconhecido como o maior representante de uma renovação estética de pós-guerra, contribuindo com a invenção mitopoética, concebendo a linguagem como valor em si. Em sua obra, busca uma linguagem original, "[...] linguagem ainda impura, mas viva, tal como o ouro recém-tirado da mina e ainda infiltrado na pedra; e que Guimarães Rosa recriou com o superior equilíbrio que lhe adveio de uma natural visão poética somada a uma sólida cultura" (COELHO, 1975, p. 205). Em "Motivo", as aventuras do menino, no início carregadas de fantasia, libertas de toda temporalidade e espacialidade, são interrompidas por uma súbita velhice. Sua juventude, impulsionadora de maravilhas e possibilidades, é amputada "bem antes de despertar". Só lhe resta regressar, voltar ao mundo real, com suas restrições, sem magia, sem vigor. Ainda nos reportando à entrevista dada a Günter Lorenz, Guimarães Rosa comenta a postura dos escritores de seu tempo, acusando-os de realizarem uma literatura local, datada, advinda de uma linguagem gasta e pobre de significado. Para ele, a maioria dos escritores escreve para o dia, e não para o infinito. É necessário renovar a língua e, dessa forma, renovar o mundo. Nosso poeta diz que

O que chamamos hoje linguagem corrente é um monstro morto. A língua serve para expressar idéias, mas a linguagem corrente expressa apenas clichês e não idéias; por isso está morta, e o que está morto não pode expressar idéias. Não se pode fazer desta linguagem corrente uma linguagem literária, como pretendem os jovens do mundo inteiro, sem pensar muito. (ROSA apud LORENZ, 1973, p. 345). 
Em "Hipotrélico" (ROSA, 1976), prefácio dedicado à questão do neologismo, Guimarães Rosa discute ironicamente a resistência que temos em aceitar a renovação linguística, no entanto, ressalta a naturalidade com que neologismos manifestam-se no ambiente popular. Após definir "hipotrélico" como "[...] antipodático, sengraçante imprizido; ou talvez, vice-dito: indivíduo pedante, importuno agudo, falta de respeito para com a opinião alheia" (ROSA, 1976, p. 64) e denunciá-lo como intolerante à aparição de palavras inventadas, conclui:

Somos todos, neste ponto [com relação à intolerância a neologismos], um tento ou cento hipotrélicos? Salvo o excepto, um neologismo contunde, confunde, quase ofende. Perspica-nos a inércia que soneja em cada canto do espírito, e que se refestela com os bons hábitos estadados. Se é que um não se assuste: saia todo-o-mundo a empinar vocábulos seus, e aonde é que se vai dar com a língua tida e herdada? Assenta-nos bem à modéstia achar que o novo não valerá o velho; ajusta-se à melhor prudência relegar $\mathrm{o}$ progresso no passado. (ROSA, 1976, p. 64).

Os devaneios, as aventuras da personagem de "Motivo" podem significar a meninice da língua, latente em suas infinitas possibilidades, mas encoberta pela velhice dos costumes, da conveniência. A viagem extraordinária empreendida pelo meninolinguagem é representada por inusitadas aproximações, que surgem nos oito primeiros versos. O menino inicia sua viagem rumo a sua elevação: "O menino foi andando/ entrou num elevador". A figura da montanha logo surge no caminho do menino, desembocando nos belos versos: "o menino saiu de selvas / montado no gurupés". A palavra gurupés, definida como "no veleiro, mastro que se lança, inclinado, do bico da proa para a frente, no plano longitudinal" (FERREIRA, 2004, p. 1018) confere ao menino a capacidade de estar à frente, no plano longitudinal, "tomado no sentido da maior dimensão". O menino, nesse momento, é todo invenção, possibilidade. No entanto, sua viagem será interrompida. Os seis últimos versos, introduzidos pela conjunção adversativa "mas", revelam um menino envelhecido "bem antes de despertar", uma linguagem engessada, presa ao costume, à tradição. É necessário despertá-la, não para a realidade que nos rodeia, mas para um tempo e um espaço original, mítico, onde a língua nos reporta ao infinito, ao outro do mundo em que se encontra a literatura. Diz Guimarães Rosa (apud LORENZ, 1973, p. 340): “O idioma é a única porta para o infinito, mas infelizmente está oculto sob montanhas de cinzas. Daí resulta que tenho de limpá-lo, e como é a expressão da vida, sou eu o responsável por ele, pelo que devo constantemente umsorgen" ("cuidar dele", em alemão).

Os oito primeiros versos acenam para uma linguagem que transcende o sentido convencional das palavras, livre para a criatividade e aberta a novos sentidos. Porém, como uma viagem, como transcendência que não consegue plenamente realizar-se, a palavra volta a ser montanhas de cinzas, por não poder livrar-se das convenções impostas pelos presentes momento e lugar.

"Motivo" e "Distância" estão entre os poemas de Ave, Palavra que apresentam narratividade. Este caráter narrativo dos poemas liga-se à questão da execução de uma viagem. Benedito Nunes (1969), em ensaio dedicado à questão da viagem, observa a presença marcante de tal elemento na obra do autor. A viagem está presente desde as narrativas de Sagarana e torna-se eixo central à elaboração de Grande Sertão: veredas. Afirma o crítico que viagem e existência confundem-se na trajetória de Riobaldo, 
unindo-se nessa viagem, por meio do relato, "os diferentes fios do Bem e do Mal, que compõem o emaranhado da existência":

Vivendo de momento a momento, de lugar a lugar, sem a compreensão da linha temporal e sinuosa que liga todos os momentos e todos os lugares da existência, só percebemos saídas e entradas, idas e vindas. Mas a viagem redonda, a travessia das coisas, - que é vivência e descoberta do mundo e de nós mesmos, nessa aprendizagem da vida, em que o próprio viver consiste - a viagem - travessia que se transvive na lembrança, constitui o saldo imponderável das ações, que a memória e a imaginação juntas recriam. (NUNES, 1969, p. 175).

Em "O aloprado", outro poema da coletânea, a personagem segue em direção ao fundo do mar. No entanto, ao adentrar o mar e conhecer seus mistérios é seu próprio coração que passa a conhecer profundamente. A personagem é nomeada por Guimarães Rosa como o aloprado, o "encantado". Sua viagem-travessia foi concluída e o saldo dessa viagem não é nada mais do que o encontro consigo mesmo. No poema "Os três burricos", o eu poético sai em errância carregando outros dois "eus" - ele mesmo - em uma trajetória marcada pela reflexão e pelo questionamento de sua existência. A narrativa não se conclui porque tampouco o eu poético chega a uma conclusão quanto à compreensão de seu ser. "Distância" também se caracteriza, como antes ressaltamos, por um poema que ilustra uma narrativa inconclusa. A associação feita entre narração e vida parece não estar apenas nos poemas rosianos. A palavra poética entendida como criação é concepção adotada por Guimarães Rosa, relacionando vida e linguagem:

Para Guimarães Rosa, não há, de um lado, o mundo, e, de outro, o homem que o atravessa. Além de viajante, o homem é a viagem - objeto e sujeito da travessia, em cujo processo o mundo se faz. Ele atravessa a realidade conhecendo-a, e conhece-a mediante a ação da poiesis originária, dessa atividade criadora, que nunca é tão profunda e soberana como no ato de nomeação das coisas, a partir do qual se opera a fundação do ser pela palavra, de que fala Heidegger. (NUNES, 1969, p. 179).

Em "Cara-de-Bronze", de Corpo de Baile, "verdadeira síntese da concepção-domundo de Guimarães Rosa", de acordo com Nunes, o motivo da viagem ressurge atrelado à questão da palavra poética:

A viagem do Grivo realiza-se como travessia por entre coisas que vão sendo nomeadas, uma a uma, detalhadamente [...]. Os nexos que ligam os diferentes momentos da travessia, e que dão acesso ao mundo natural e humano, enfim conhecido e possuído, através do logos poético que o recriou, só se produzem, sob forma de narrativa, na viagem concluída.”. (NUNES, 1969, p. 184, grifo do autor).

Também em "Distância" a narrativa só se concluiria se o cavaleiro atingisse a madrugada, o "outro lado". No entanto, a travessia não se realiza e a composição converte-se em poema da narrativa frustrada. É necessário ressaltar que o poema como composição poética realiza-se, com destaque a construções imagéticas e utilização de recursos sonoros interessantes. Mas é a história que ele conta que não se realiza, assim como também não se realiza a transcendência das personagens criadas. 
Ainda dentro da questão da metapoesia nos poemas de Ave, Palavra, analisemos o poema "Escólio" (p. 175):

\author{
ESCÓLIO \\ O que sei, não me serve. \\ Decoro o que não sei. \\ Relembro-me: \\ deslumbro-me, desprezo-me. \\ O querubim é um dragão \\ suas asas não se acabam. \\ Sempre ele me acha em falta \\ ou no remorso de tanta lucidez. \\ Somos, anciãos, amargos. \\ Tão amargos, juntos, \\ que temos de construir \\ do nada - \\ que é humano e nos envolve. \\ A gente tem de tirar dele \\ algo, pedaço de alto: \\ alma, amor, praga ou poema.
}

Em "Escólio", o poeta questiona-se sobre seu saber e cria a figura do querubim que atua como propiciadora de conhecimento. Rejeita o que sabe; não lhe serve, diz o eu poético. O que quer é o que não sabe, e ele o decora, o aprende de cor, de coração. Interessante notar que, na introdução feita por Guimarães Rosa a Sá Araújo Ségrim, autor anagramático ao qual é atribuído tal poema, o escritor descreve suas composições referindo-se ao seu não saber:

SE NÃO LHE FIRO A MODÉSTIA, direi aqui, depressa, que SÁ ARAÚJO SÉGRIM, em geral, agradou. Por isso mesmo, volta, hoje, com novos poemas, que só não sei se escolhemos bem. Sendo coisas mui sentidas. Sendo o que ele não sabe da vida. Digamme o mais, amanhã. Leiam-no, porém. (ROSA, 1970, p. 174).

O eu poético apreende o "não saber" pela via do coração. Esse "não saber" apreendido o faz relembrar, e o poeta reforça a íntima relação entre as ações por meio da aliteração: "Relembro-me: / deslumbro-me, desprezo-me". Por sua vez, ao versar sobre a revelação do sagrado, Octavio Paz (1982, p. 161) afirma que, às vezes, sem causa aparente, vemos a verdade que nos rodeia, e que essa visão é uma espécie de teofania ou aparição, pois o mundo se revela para nós em suas dobras e abismos: "Um sopro nos golpeia a fronte. Estamos encantados, suspensos no meio da tarde imóvel. Adivinhamos que somos de outro mundo. É a 'vida anterior' que retorna”. Ao apreender o não sabido pela via do coração, é dado ao eu poético de "Escólio" relembrar-se, retornar à vida ou experiência anterior. Sua primeira reação é a de deslumbramento, fascinação, seguida de rejeição, repulsa: o eu poético reconhece a sua mortalidade. Os quatro versos seguintes convertem em imagem a revelação ofertada ao poeta. "O querubim é um dragão/ suas asas não se acabam./ Sempre ele me acha em falta/ ou no remorso de tanta lucidez". É por meio do outro que o eu poético se vê. Sua presença mostra o verso e o reverso do eu, torna-se o seu reflexo. "Presença estranha somos nós também. Isso que me repele, 
me atrai. Esse outro é também eu. A fascinação seria inexplicável se o horror ante a 'outridade' não estivesse, pela raiz, cingido pela suspeita de nossa identidade final com aquilo que nos parece tão estranho e alheio" (PAZ, 1982, p. 160-161). A figura que possibilita o eu poético de "Escólio" de revelar-se, de vislumbrar seu estado de lucidez, de luz, é o querubim metaforizado em dragão. O que aqui se assinala no anjo não é a beleza, a visão do mensageiro da paz, e sim algo que nos aproxima do temível, do ser fabuloso que, na maioria das vezes, é representado com cauda de serpente, garras e asas, mas que a mitologia chinesa traz como característica o poder da renovação.

Ao relembrar-se, ao retornar à vida ou experiência anterior, diz o eu poético que se deslumbra. Deslumbrar pode ser entendido como "1. Ofuscar ou turvar a vista de, pela muita luz ou pelo brilho excessivo; encandear; translumbrar. 2. Perturbar o entendimento de. 3. Causar assombro a; maravilhar, fascinar. 4. Seduzir; fascinar; 5. Causar deslumbramento. 6. Ofuscar ou turvar a vista. 7. Deixar-se fascinar ou seduzir" (FERREIRA, 2004, p. 653, grifo nosso). A figura da luz que ofusca está presente em contos de Primeiras Estórias. O protagonista de "O espelho", após muito perseguir a sua "vera forma", que acreditava poder vislumbrar frente ao espelho, encontra a "forma vazia, sem imagem, luz, transparência, nada": "Simplesmente lhe digo que me olhei num espelho e não me vi. Não vi nada. Só o campo, liso, às vácuas, aberto como o sol, água limpíssima, à dispersão da luz, tapadamente tudo." (ROSA, 1972, p. 76).

Para Heloisa Vilhena de Araujo (1998, p. 37), o herói de "O espelho", ao deparar-se com o espelho vazio, estava tendo uma visio intellectualis. Assim como São Paulo que "levantou-se e, com olhos abertos, não via nada", é dado ao protagonista do conto rosiano o conhecimento direto de Deus:

O que aparece e não aparece no espelho de "O espelho" - "água limpíssima, à dispersão da luz, tapadamente tudo" (p. 76) -, no espelho da superfície do rio de "A terceira margem do rio", é assim, a essência da Verdade, o que estrutura, secretamente, o homem enquanto tal - o homem humano. É ela que o libera para seu ser próprio, no tempo, para sua história própria, enquanto mantém-se escondida: que o libera para o seu errar, para os seus excessos, em direção à morte ou à vida, à destruição ou à criação, ao mutismo ou à linguagem, à regressão ou ao amadurecimento." (ARAUJO, 1998, p. 237, grifo nosso).

Em "Escólio", a revelação concretiza-se com a visão do querubim, que, de acordo com Santo Agostinho (apud ARAUJO, 1998, p. 36), é também realidade que se pode conhecer através da visio intellectualis, a mais alta modalidade de visão que o homem pode ter, possibilitando-lhe a consciência da mortalidade, da humanidade. A partir do momento em que o anjo possibilita a revelação de si mesmo ao eu poético, ele se põe a versar sobre o que pode construir, o que pode realizar. É do nada que nascerá a nova experiência: alma, amor, praga ou poema. Dessa forma, o eu poético reconhece sua identidade, sua capacidade de escolha, seu poder de construir sua história, de realizar-se como homem humano.

A pesquisa do caráter metapoético de "Escólio" pode-se iniciar pelo título. Ao investigá-lo, encontramos sua definição como "comentário destinado a tornar inteligível um autor clássico. Um esclarecimento, uma explicação ou interpretação de um texto" 
(FERREIRA, 2004, 792). Tal definição possibilita uma segunda leitura do poema: ele versaria sobre a preocupação do poeta em pensar o próprio fazer poético. Os oito primeiros versos são regidos pela primeira pessoa do singular; o poeta espreita sua forma de conceber a criação literária. O poeta é um escoliasta.

Uma figura criada que aproxima mais tal composição da discussão do fazer literário é a do dragão, monstro fabuloso que habita o mundo do imaginário, pertencente, então, ao universo ficcional. A lucidez que o eu poético diz estar às vezes ausente ou completamente presente em si também pode nos remeter à ideia de estarmos diante ou não da manifestação da inspiração.

O processo de criação rosiano é um dos temas abordados pela entrevista a $\mathrm{G}$. Lorenz. Embora admita que trabalhe duro e aplicadamente, Guimarães Rosa declara que há algo que o impulsiona a escrever, alheio à sua vontade:

Não preciso inventar contos, eles vêm a mim, me obrigam a escrevê- los. Acontece-me algo assim como vocês dizem em alemão. Mich reitet auf einmal der Teufel ("De repente o diabo me cavalga"), que neste caso se chama precisamente inspiração. Isto me acontece de forma tão consequente e inevitável, que às vezes quase acredito que eu mesmo, João, sou um conto contado por mim mesmo (ROSA apud LORENZ, 1973, p. 327).

Na correspondência entre Edoardo Bizzarri (1981, p. 58) e Guimarães Rosa, este faz novamente referência a seu processo de criação:

Ora, você já notou, decerto, que, como eu, os meus livros, em essência, são "antiintelectuais" - defendem o altíssimo primado da intuição, da revelação, da inspiração, sobre o bruxolear presunçoso da inteligência reflexiva, da razão, a megera cartesiana. Quero ficar com o Tao, com os Vedas e Upanixades, com os Evangelistas e São Paulo, com Platão, com Plotino, com Bergson, com Berdiaeff - com Cristo, principalmente.

Assim como Rosa, Paz (1982, p. 194) afirma que tanto o poeta inspirado como o artesão são acometidos do que ele chama de "irrupção da vontade alheia". Nos versos seguintes, o poeta inclui-se em um grupo: "Somos, anciãos, amargos". O verbo ser, assim, isolado, conquista um sentido absoluto. Cria uma tensão na construção do verso; espera-se que ele atue como verbo de ligação, possibilitando a predicação do sujeito, mas o que é valorizado é uma espécie de intransitividade do verbo: Somos. O poeta é, especialmente, ser. A partir desse verso, não se trata mais de criação particular, mas sim de se fazer referência a todos os poetas. Prestigia, assim, o fazer poético de todos os tempos e espaços.

Atentando-nos ao termo "anciãos", percebemos que a ideia de sabedoria contida nessa palavra é recorrente ao longo da produção rosiana. Além de personagens no universo narrativo que relacionam velhice e sabedoria, a introdução feita por Guimarães Rosa ao anagramático Soares Guiamar apresenta um aforismo dedicado ao poeta e à poesia, em que tal ideia surge: "Ser poeta é já estar em experimentada sorte de velhice. Toda poesia é também uma espécie de pedido de perdão" (ROSA, 1970, p. 50, grifo nosso). A velhice do poeta, o seu estado de ancião, reporta-nos à questão do refletir, do 
estar voltado para o poético. Em O Arco e a Lira, Paz (1982, p. 213) diz que, independentemente de qual seja a forma de criação, se através da inspiração ou da construção, o refletir é condição essencial para a criação poética: "A pré-meditação é o traço determinante do ato de criar e aquilo que o torna possível. Sem pré-meditação não há inspiração ou revelação da outridade". Ao ressaltar a intransitividade do verbo "ser", Rosa dá a "anciãos" a função de substantivo. Dessa forma, reafirma o espírito reflexivo, de pré-meditação do poeta.

A presença e reiteração do adjetivo "amargos", intimamente associado à construção poética, reporta-nos à ideia heideggeriana da angústia como uma das vias para atingirmos a condição original. Para o poeta de "Escólio", o estado de amargura leva os poetas a construírem do nada, os faz produzir, criar: "A gente tem de tirar dele/ algo, pedaço de alto:/ alma, amor, praga ou poema". Paz apregoa que o nada não é algo exterior a nós, é, antes, fundamento para o ser. A voz que fala em "Escólio" compartilha da concepção do ensaísta ao dizer "que temos de construir/ do nada -/ que é humano e nos envolve" (grifos nossos). A questão do nada reaparece em "Os três burricos", através do questionamento do eu poético: "Também não sei se é uma ida/ ao inverso: se regresso. / Muito é o nada nesta vida" (p. 54). Para Octavio Paz, o nada, a origem, atualiza-se na poesia através do silêncio, "que é como um lago, uma superfície lisa e compacta. Dentro, submersas, as palavras aguardam. E é preciso descer, ir ao fundo, calar, esperar. A esterilidade precede a inspiração, como o vazio precede a plenitude" (PAZ, 1982, p. 179). Para o poeta de "Escólio", o nada precede a criação poética.

"Tornamento" (p. 175), do anagramático Sá Araújo Ségrim, também é um poema de cunho metapoético:

\section{TORNAMENTO}

- I -

A viagem dos teus cabelos -

estes cabelos povoariam legião de poemas

e as borboletas circulam indagando tua cintura, incertamente. Teu corpo em movimento

detém uma significação de perfume.

$\mathrm{O}$ som de um violino conseguiria dissolver

um copo de ouro?

- II -

Houve reis que construíram seus nomes milenários

e poetas que governam palácios em caminhos,

Povos. Proêmios. Penas.

Mas toda você, um gosto só, matar-me-ia a sede

e teus pés e rosas.

- III -

Às vezes - o destino não se esquece -

as grades estão abertas,

as almas estão despertas:

às vezes,

quando quanda, 
quando à hora,

quando os deuses,

de repente

- entes -

a gente

se encontra.

Um traço que singulariza essa poesia é a sua disposição. Ela vem distribuída em três partes, como se a destacar nuances diferentes de um mesmo tema. A princípio acredita-se que o poeta esteja falando sobre a mulher amada, mas a inserção do sexto e sétimo versos faz-nos questionar qual é o objeto de desejo a que o poeta se refere.

A primeira parte, de tom um tanto erótico, é constituída de elementos sinestésicos. Os cabelos da amada povoariam legião de poemas. A palavra legião, "grande quantidade de anjos", reporta-nos à figura do querubim do poema anterior e de outros já aqui mencionados. Mas os seres alados neste poema são as borboletas. Elas investigam, indagam a cintura do ser amado - como a aludir à fertilidade - que, de acordo com o poeta, detém uma significação de perfume. Logo após essas imagens, um questionamento curioso: "O som de um violino conseguiria dissolver/ um copo de ouro?". Distintamente, a segunda parte adquire um tom sério, com sabor de reflexão histórica, referindo-se a poetas e reis, sugerindo-nos o poder advindo da palavra: "Houve reis que construíram seus nomes milenários/ e poetas que governam palácios em caminhos,/ Povos. Proêmios. Penas.”. Para Octavio Paz, a história do homem poderia se reduzir à história das relações entre as palavras e o pensamento, o homem caracterizando-se como um ser de palavras: "Esquece-se com frequência que, como todas as outras criações humanas, os Impérios e os Estados estão feitos de palavras: são feitos verbais" (PAZ, 1982, p. 35-36). Guimarães Rosa (apud LORENZ, 1973, p. 348) também se refere ao poder da palavra ao associar poesia e religião: "A religião é um assunto poético e a poesia se origina da modificação de realidades linguísticas. Desta forma, pode acontecer que uma pessoa forme palavras e na realidade esteja criando religiões. Cristo é um bom exemplo disso". O poeta de "Tornamento" poderia estar se referindo, então, a pessoas, reis e poetas que utilizaram e utilizam a palavra como forma de poder.

Pode-se, então, ler o questionamento anterior como uma alusão ao poder das palavras de transformar a realidade, metonimicamente aqui representadas por sua face sonora: "O som de um violino conseguiria dissolver/ um copo de ouro?". Mas o poeta diz-se interessado na palavra em sua pureza, "um gosto só" lhe satisfaz. Este "gosto só" defendido pelo poeta não é, como se poderia imaginar, o sentido único, mas o sentido puro, em suas infinitas facetas, a que alude através da sinestesia mencionada na estrofe anterior. $O$ poeta não se refere também a qualquer som e, sim, ao som de um violino, próximo, portanto, da arte. Estamos lidando com a palavra literária.

$\mathrm{Na}$ última parte, o poeta volta-se para a revelação poética, para o momento de reconhecimento de que nos fala Paz, quando o homem supera sua carência e se realiza como ente, ser, quando ao poeta é revelada a palavra transformada em arte:

Um momento raro de neologismo nas poesias rosianas: "quando quanda". Além de explorar a sonoridade das palavras, Guimarães Rosa concede à poesia, o que é 
comum nas composições em prosa, um processo neologístico apresentado por Coutinho (1991, p. 212) como "criação interparadigmática", que consiste na formação de vocábulos derivados de cognatos pertencentes a classes gramaticais diferentes. Em "Tornamento", o termo "quanda", posto ao lado do advérbio que lhe deu origem, intensifica o aspecto temporal, reforçado por expressões como "às vezes", "hora", "de repente", conferindo ao verso um caráter lúdico.

\section{Considerações finais}

Ainda que os poemas apresentados aproximem-se pela dedicação à metapoesia, cada composição utiliza linguagem e enfoque distintos. Em "Distância", o poeta, através de uma linguagem simbólica, ilustra a criação literária por meio da construção de uma narrativa interna. "Motivo" apresenta-se como alegoria da palavra poética que não se realiza por culpa do conservadorismo linguístico. Já em "Escólio", o poeta versa sobre a revelação literária, enquanto "Tornamento", ao tomar a poesia como musa, trata da revelação poética e do poder da palavra de transformar e criar a realidade.

A aproximação das poesias com outros textos do autor evidenciou que elas compartilham das inquietações presentes em sua obra como um todo, no que diz respeito ao fazer literário. Por meio de uma linguagem concisa e sugestiva, o escritor foi capaz de alcançar a linguagem poética, relacionando mais uma vez os aspectos metafísico e metaliterário. O desejo de apresentar a palavra a partir de uma dimensão metafísica percorre sua obra, bem ilustrado no trecho de "Aletria e hermenêutica": "A vida também é para ser lida. Não literalmente, mas em seu supra-senso. E a gente, por enquanto, só a lê por tortas linhas". (ROSA, 1976, p. 04). Dessa forma, o autor mineiro confere à arte literária o poder de salvação. Ressaltar tais aspectos metaliterários em seus poemas é mais uma forma de evidenciar que estes dialogam com a essência de sua prosa.

\section{REFERÊNCIAS}

ARAUJO, H. V. de. O espelho: contribuição ao estudo de Guimarães Rosa. São Paulo: Mandarim, 1998.

BIZZARRI, E. J. Guimarães Rosa: correspondência com seu tradutor italiano Edoardo Bizzarri. 2. ed. São Paulo: T. A. Queiroz, Instituto Cultural Ítalo-Brasileiro, 1980. (Biblioteca de Letras e Ciências Humanas, série 1: Estudos Brasileiros, 2).

COELHO, N. N. Guimarães Rosa e a tendência regionalista. In: ÁVILA, A. (Org.). O Modernismo. São Paulo: Perspectiva, 1975. p. 203-211.

COUTINHO, E. Guimarães Rosa e o processo de revitalização da linguagem. In: _. (Org.). Guimarães Rosa. Rio de Janeiro: Civilização Brasileira/ INL, 1991. p. $202-234$. (Fortuna crítica).

FANTINI, M. Guimarães Rosa: fronteiras, margens, passagens. São Paulo: Ateliê Editorial, 2004.

FERREIRA, A. B. de H. Novo dicionário Aurélio da língua portuguesa. 3. ed. Curitiba: Positivo, 2004. 
LEONEL, M. C. Guimarães Rosa: Magma e gênese da obra. São Paulo: Editora UNESP, 2000.

LEVY, T. S. A experiência do Fora: Blanchot, Foucault e Deleuze. Rio de Janeiro: Dumará, 2003.

LORENZ, G. W. Guimarães Rosa. In: Diálogo com a América Latina: panorama de uma literatura do futuro. Tradução de R. C. Abílio e F. de S. Rodrigues. São Paulo: E. P. V., 1973.

MACIEL, M. E. Poéticas da lucidez. In: . Vô transverso: poesia, modernidade e fim do século XX. RJ/ BH: Sette Letras, FALE-UFMG, 1999.

NUNES, B. Guimarães Rosa. In: O dorso do tigre. São Paulo: Perspectiva, 1969. p. 143-210.

PAZ, O. A outra voz. Tradução de W. Dupont. São Paulo: Siciliano, 1993. . O arco e a lira. Tradução de O. Savary. Rio de Janeiro: Nova Fronteira, 1982. ROSA, J. G. Ave, palavra. Rio de Janeiro: J. Olympio, 1970. . Tutameia (terceiras estórias). Rio de Janeiro: J. Olympio, 1976.

Recebido em: 30/08/2017

Aprovado em: 31/10/2017 